\title{
15 and 16 Years-Old Students' Understanding of Factors That Influence Water Pollution
}

\author{
Neva Rebolj ${ }^{1} \&$ Iztok Devetak ${ }^{1}$ \\ ${ }^{1}$ University of Ljubljana, Faculty of Education, Kardeljeva pl. 16, 1000 Ljubljana, Slovenia \\ Correspondence: Iztok Devetak, University of Ljubljana, Faculty of Education, Kardeljeva pl. 16, 1000 Ljubljana, \\ Slovenia. E-mail: iztok.devetak@pef.uni-lj.si
}

Received: January 14, 2013

Accepted: March 2, 2013 Online Published: March 28, 2013

doi:10.5539/eer.v3n1p106

URL: http://dx.doi.org/10.5539/eer.v3n1p106

\begin{abstract}
Considering current environment condition, we should finally pay much more attention to environmental education. One of the methods, which would contribute to better environmental education, is of course including more environmental content to secondary school curriculum. Based on this, we would be able to expect the student's knowledge of water pollution factors to improve. 281 of first and second year students of health care school, nursing care program, participated in this research. Data were collected by analyzing test papers about water pollution factors. We have also made knowledge comparison about water pollution factors between 15 (first year of secondary school) and 16 year (second year of secondary school) old students. The results indicated that second year students achieved statistically significantly better results than first year students at the water pollution test paper. The difference results in the fact that second year students have already listened to the content of environmental pollution, which first year students had yet to hear. Results also show that first and second year students were more successful at answering general questions, which do not demand much of detailed environmental knowledge.
\end{abstract}

Keywords: environmental education, secondary school students' knowledge of water pollution factors

\section{Introduction}

\subsection{Environmental Education}

Environmental education (EE) is nowadays a topic of many seminars and conferences, where it is being discussed, how to bring knowledge of the environment and its laws closer to the people and that such education would have the effect of environmental protection of the individual, a society and a global population. In other words, environmental education seeks to empower individuals to understand environmental problems and to improve their ability to solve them (McCue, 2003). Environmental education has been suggested as one of the most effective ways to respond to environmental threats (Teksoz, Sahin, \& Ertepinar, 2010). Many environmental education programs do not provide individuals with practical and useful information on how to deal with the environment in which they live. The Tbilisi Declaration, (www.naaee.org) and United Nations Environmental, Scientific, and Cultural Organization (www.naaee.org) agree the EE's goals should be focused on three fundamental aspects: (1) building awareness among individual citizens and community groups about the impact of the social, economic, political and ecological practices on the environment; (2) providing education opportunities for citizens so they acquire the necessary skills, knowledge, values and attitudes for environmental protection, and (3) fostering action-oriented behaviours towards environmental conservancy and sustainability. Consequently, the main emphasis of environmental education programs should be to change the individual's attitude towards the environment with a deeper understanding of the environment (O'Connor \& Pooley, 2000). Environmental education is not limited only on formal education, but appears in many forms of informal education (Flowers, Guevara, \& Whelan, 2009), for example: project work, workshops, field trips, museums, zoos, botanic gardens, etc. Similar views on the goals that environmental education should be accomplished in both formal and informal education have been submitted by others (E. Jeronen, J. Jeronen, \& Raustia, 2008; Palmer \& Neal, 1994). Most countries in the world understand the importance of EE, so it is incorporated into formal education. Most agree that $\mathrm{EE}$ is compatible with other science disciplines in the field of education, but there is much more emphasis on the central areas of science, such as biology, chemistry and physics. The first efforts to include environmental education in Latin America have been introduced in the form of informal educational programs 
(González-Gaudiano, 2007). Currently in the United States, a lot of attention and support is devoted to include environmental education back into the curriculum (Campbell, Medina-Jerez, Erdogan, \& Zhang, 2010). Davis and Elliott (2003) have found out that the field trip in kindergarten, as part of environmental education, particularly contributed to memorizing what has been heard and seen. After one year, children could still remember a lot of things from the field trip. Benton, Farmer and Knapp (2007) studied environmental education at an early age and made similar conclusions.

\subsection{Teacher Education about Environment}

In the world, Environmental Education is a priority in teacher education since the end of the twentieth century. New theories and techniques that have emerged in teacher education require the skills and knowledge used in practical terms (Teksoz et al., 2010). As stated by Miles and Cutter-Mackenzie (2006), teacher education for implementing environmental education in their classrooms can be defined as a "priority of priorities". Fien and Tilbury (1996) argue that the inclusion of environmental education in teacher education is "as an incentive for its introduction into the school curriculum" and in particular to "develop an effective course for training teachers in environmental education would result in innovation in the curriculum." Many researchers (Ballantyne, 1995; Cutter-Mackenzie, 2003; Jenkins, 1999-2000; Mastrilli, 2005; Mckeown-Ice, 2000; Powers, 2004; Spork, 1992; Tilbury, 1992, 1993, 1994) argue that the lack of pre-service and in-service teacher training in environmental education is the one that presents the major barrier that is preventing and/or limiting the effective implementation of environmental education in primary schools. From their research about the level of environmental knowledge of Michigan State University students, Kaplowitz and Levine (2005) concluded that increasing the level of environmental knowledge of tomorrow's teachers may be possible and also prosperous and that more research is needed to determine the role that teachers and their education play in the environmental education of their students. In the United States environmental education study, McKeown-Ice (2000) suggested, that there is a need for such studies to determine if correlations between environmental literacy, environmental education teaching competencies, and teacher preparation program level of involvement in environmental education exist. In the study about elements of success on environmental education, Theodore (2000) emphasized the importance of taking data from environmental education practitioners. He set three categories for developing elements of success in environmental education framework as: teaching conditions, teacher competencies and teaching practices. Environmental educators should possess the understandings, skills and attitudes associated with environmental literacy. These competencies have been defined in details in Excellence in Environmental Education-Guidelines for Learning (Pre K-12), published by the North American Association for Environmental Education (Teksoz et al., 2010). In three major teacher-training colleges, Goldman, Yavetz and Peer (2006) investigated the relationship between future teachers, environmental behaviour and background. They also worked on the environmental literacy of teacher training in Israel. Their study revealed that those future teachers manifest a low level of environmental literacy which was reflected in their environmental behaviour. Students majoring in fields related to the environment showed more knowledge about the environment compared to students of other disciplines. These findings are related to Arcury's (1990) views that "Increased knowledge about the environment is assumed to Change Environmental Attitudes" (p. 300). In Turkey, the Ministry of Education (MNE, 2005) only now plans to include environmental issues in science subjects in school curriculum. Some environmental issues such as endangered species, recycling, water pollution, energy use and deforestation are included in the newly developed curriculum of basic science. However, environmental education has been made a compulsory part of teacher education, despite the fact that new objects are linked to environmental issues. Therefore it became important to assess the environmental knowledge of pre-service teachers, and that environmental education should be made an integral part of teacher education (Teksoz et al., 2010).

\section{Materials and Methods}

\subsection{Research Problem and Research Questions}

In Slovenia, there is not much attention paid to the environmental education. In many high schools students do not learn much about the environment. We mean mostly secondary technical and vocational schools, where the emphasis is on the profession, so the majority of the lessons is devoted to practical training. In chemistry class the students should be taught the main causes of air, water and soil pollution and their consequences on people's health and lives. In healthy nutrition class they should be taught about the importance of clean drinking water intake and its laws (http://portal.mss.edus.si/msswww/programi2011/programi/Ssi/KZ-IK/katalog.htm). If environmental concepts are included in some high schools curriculum, there are usually not enough lessons to include environmental education into the actual classroom activities. On closer examination of biology and chemistry curriculum in vocational school, we can see that in the biology class students do not hear anything about the environment, while in the chemistry curriculum there is a section Chemistry and environment, where students 
learn some basic concepts about the contaminants in air, soil and water (Poberžnik et al., 2007; Zupančič, Vičar, Gobec, \& Mršić, 2007). Teachers also play an important role in educating students by setting an example of how to deal with environmental issues. Two basic research questions are based on the research problem described above: (1) How deeply do students aged 15 to 16 years understand the factors that contribute to water pollution? (2) Are the differences in the knowledge of first and second year students statistically significantly different?

\subsection{Sample}

The study involved 281 students, of which 144 (51\%) were first-year students and 137 (49\%) were second year students of secondary medical school, majoring in Nursing. The sample comprises $2 / 3$ female and $1 / 3$ male students. Students came from different parts of Slovenia. They first encountered chemistry concepts (also connected with environmental issues) in the first and second periods of the primary school (age 6 to 11) and more in-depth in 105 hours of Science in $7^{\text {th }}$ grade (age 12) and 70 hours of chemistry in eighth grade and 64 hours of chemistry in ninth grade (age 13 and 14). In elementary school students also had a chance to select an optional subject such as Experiments in chemistry, Chemistry in life or Chemistry in the environment, in the extent of 35 hours and also Environmental Education I, II and III. In a secondary medical school students only had 70 hours of chemistry in the first year. Similarly students first came across biology in first and second period of elementary school and studied it more thoroughly in the third period (grades 7 to 9). They had 52.5 hours of biology in eighth grade and 70 hours in ninth grade. They could also choose an optional subject Organisms in natural and artificial environment in the extent of 35 hours in seventh and eighth grade and 32 hours in ninth grade. In secondary medical school students only had 70 hours of biology in the first year.

\subsection{Instrument}

Data were collected with a quantitative data collection technique; students answered the test paper questions. The test comprised seven multiple-choice questions with the possibility of their opinion, which was not in the answers. Overall, students could achieve 7 points. The questionnaire covered some well known issues and also some issues where it was necessary to show some knowledge. As well known issues we asked students what they think is polluting the river the most and what can be inferred if there are no fish in the water. The questions that required some knowledge were the following; we were interested in which substances are present in the water, if the analysis shows the presence of ammonia and nitrate. What does it mean that the river has a self-cleaning function and what happens if there is an excessive growth of green algae in the river. We were also interested in what parameters can be found with physical indicators of water pollution.

\subsection{Research Design}

In this study we used the descriptive method. Test was applied in a group during the class under standard conditions. They needed an average of 10 minutes to finish it. The test was anonymous and the data was used only for the purposes of this study. The data were statistically analyzed using computer program Excel and the statistical program Statistical Package for the Social Sciences (SPSS). The following tests were used for the analysis of the results within the program SPSS: t-test, $\chi^{2}$-test (this test of independence was used because we have two groups of students and five possible values of nominal variables) and frequencies of responses in each item.

\section{Results and Discussion}

The results show that there is a statistically significant difference in students' understanding of water pollution factors between the first- $($ mean $(M)=3.8$, standard deviation $(\mathrm{SD})=1.3)$ and second-year students $(\mathrm{M}=4.14$, SD $=1)(\mathrm{t}(279)=-2.142, \mathrm{p}=0.03)$. On average, first-year students reached $54.3 \%$ of total points and second-year students $59 \%$ of total points. The students' achievements show quite average knowledge of factors that cause the water pollution. Second-year students understand the water pollution factors a bit better, as they had chemistry in the first year of secondary school, where they had conducted experiments on water pollution and have acquired knowledge by practical work, which they have memorized. By the time the research was conducted, first-year students have not yet been involved into the contents of chemistry and biology, which would relate only to water pollution and its consequences on the organisms. The reason for a weaker performance of the first-year students could also be that they have forgotten certain information related to the river pollution from the primary school, but the second-year students' achievements were not much better than their first-year peers. Table 1 shows the detailed analysis of the differences between students' achievements in the first- and second-year. 
Table 1. Proportion of the first- and second-year students' achievements and the significance of the difference in achievements between them at the specific item

\begin{tabular}{|c|c|c|c|c|c|c|c|}
\hline \multirow{2}{*}{ Item $^{\mathrm{a}}$} & \multicolumn{2}{|c|}{ Grade 1} & \multicolumn{2}{|c|}{ Grade 2} & \multirow{2}{*}{$\begin{array}{l}\text { The differences between } 1^{\text {st }} \text { and } \\
2^{\text {nd }} \text { grade students' achievements }\end{array}$} & \multirow{2}{*}{$\chi^{2 \mathrm{~b}}$} & \multirow{2}{*}{$\mathrm{p}$} \\
\hline & $\mathrm{f}$ & $\%$ & $\mathrm{f}$ & $\%$ & & & \\
\hline Item 1 & 55 & 19.6 & 70 & 24.9 & +5.3 & 4.731 & $\mathbf{0 . 0 3}$ \\
\hline Item 2 & 88 & 31.3 & 103 & 36.7 & +5.4 & 6.385 & 0.01 \\
\hline Item 3 & 31 & 11.0 & 25 & 8.90 & -2.1 & 0.473 & 0.49 \\
\hline Item 4 & 88 & 31.3 & 82 & 29.2 & -2.1 & 0.046 & 0.83 \\
\hline Item 5 & 130 & 46.3 & 128 & 45.6 & -0.7 & 0.929 & 0.34 \\
\hline Item 6 & 63 & 22.4 & 79 & 28.1 & +5.7 & 5.438 & 0.02 \\
\hline Item 7 & 90 & 32.0 & 78 & 27.8 & -4.2 & 0.905 & 0.34 \\
\hline
\end{tabular}

Notes:

${ }^{\mathrm{a}}$ Items:

Item 1: What do you think is polluting our water the most?

Item 2: What could be in the water, if the analysis of the water proves the presence of ammonia?

Item 3: What could be in the water, if the analysis of the water proves the presence of nitrates?

Item 4: What happens to the animals in the river when the excessive growth of green algae appears?

Item 5: What can you conclude if there are no fish in the water?

Item 6: What does it mean that the river has a self-cleaning function?

Item 7: What can be found with chemical indicators of water pollution?

${ }^{\mathrm{b}} \mathrm{df}=1$ at all $\chi^{2}$ tests.

Statistically significant differences $(\mathrm{p}<0.05)$ in the understanding of factors that influence water pollution, depending on the students' year of schooling, have been identified in questions 1,2 and 6. Second-year students answered all three questions better than first-year students. From these results we can conclude that second-year students are more familiar with the water pollution factors. In general, the first-year students were better at answering the questions, since the proportion of the correct answers was better in four out of the seven questions, but these differences are statistically not significant. In both grades, students achieved the best result in item 5, which relates to what may be inferred if we do not see any fish or plants in the water. The worst result was also achieved by both grades in item 3, which was asking about knowing the importance of nitrates in the water. Analysis of the data showed that students in both grades answered more accurately at more general questions, whose content is often presented in the form of informal education, such as workshops, project work, field trips ... Items that demanded more specific knowledge, especially those including chemistry were the ones where the answers were incorrect in more cases. Table 2 shows the frequency and ratio of different answers to multiple choice items for each grade.

Table 2. Frequencies and proportions of individual responses in both grades to the first item

\begin{tabular}{lcccccccc}
\hline \multirow{2}{*}{$\begin{array}{l}\text { What do you think is polluting our } \\
\text { water the most? }\end{array}$} & \multicolumn{2}{c}{ Households } & \multicolumn{2}{c}{ Municipal sewage } & \multicolumn{2}{c}{ Industry } & \multicolumn{2}{c}{ Agriculture } \\
\cline { 2 - 9 } & $\mathrm{f}$ & $\%$ & $\mathrm{f}$ & $\%$ & $\mathrm{f}$ & $\%$ & $\mathrm{f}$ & $\%$ \\
\hline Grade 1 & 15 & 10.0 & 69 & 48.0 & 55.0 & 38.0 & 5 & 3.5 \\
Grade 2 & 14 & 10.2 & 50 & 36.5 & 70.0 & 51.1 & 3 & 2.2 \\
\hline
\end{tabular}

In the first item students had to decide about who or what is polluting water the most. First-year students most frequently selected municipal sewage, while second-year students mostly selected industry. Municipal sewage and the industry are those two sources of water contaminants, which are most frequently exposed and are frequently present in the media. From the results we can conclude that students monitor the media and are aware of the most common factors of water pollution. 
Table 3. Frequencies and proportions of individual responses to the second item in both grades

\begin{tabular}{lccccccccc}
\hline \multirow{2}{*}{$\begin{array}{l}\text { What could be in the water, if the } \\
\text { analysis of the water proves the } \\
\text { presence of ammonia? }\end{array}$} & \multicolumn{2}{c}{ Slurry } & \multicolumn{2}{c}{ Too many plants } & \multicolumn{2}{c}{ Too many animals } & \multicolumn{2}{c}{ Washing powder } \\
\cline { 2 - 9 } & $\mathrm{f}$ & $\%$ & $\mathrm{f}$ & $\%$ & $\mathrm{f}$ & $\%$ & $\mathrm{f}$ & $\%$ \\
\hline Grade 1 & 88 & 61.1 & 12 & 8.3 & 3 & 2.1 & 41 & 28.5 \\
Grade 2 & 103 & 75.2 & 11 & 8.0 & 5 & 3.6 & 18 & 13.1 \\
\hline
\end{tabular}

The second item (Table 3) was asking the students about what is the most possible source of ammonia in the water, if the analysis proves the presence of ammonia. Students of both grades have most often selected the answer slurry. It can be concluded that the students are familiar with the problem of negligent use of manure on farmland and other land used for agriculture and that slurry is a possible source of ammonia in the water, not only fertilizers that are used in the extensive agriculture.

Table 4. Frequencies and proportions of individual responses to the third item in both grades

\begin{tabular}{lcccccccc}
\hline What could be in the water, if the analysis of & \multicolumn{2}{c}{ Fertilizers } & \multicolumn{2}{c}{ Salts } & \multicolumn{2}{c}{ Acids } & \multicolumn{2}{c}{ Plants } \\
\cline { 2 - 9 } the water proves the presence of nitrates? & $\mathrm{f}$ & $\%$ & $\mathrm{f}$ & $\%$ & $\mathrm{f}$ & $\%$ & $\mathrm{f}$ & $\%$ \\
\hline Grade 1 & 31 & 21.5 & 64 & 44.4 & 49 & 34.0 & 0 & 0.0 \\
Grade 2 & 25 & 18.2 & 70 & 51.1 & 37 & 27.0 & 5 & 3.6 \\
\hline
\end{tabular}

The third item (Table 4) was asking about what is the most possible source of nitrates in the water, if the analysis proves the presence of nitrates. Students of both grades mostly selected the answer salts, which is obviously not correct. If the water analysis shoves the presence of nitrates, it is a result of fertilizers in the water. The conclusion is that students are not familiar with the problem of excessive use of fertilizers in agriculture, and that they connect the nitrates with salts. Chemically nitrates are salts, but the sources of nitrates in the water are not salts in general, but fertilizers.

Table 5. Frequencies and proportions of individual responses to the fourth item in both grades

\begin{tabular}{|c|c|c|c|c|c|c|c|c|}
\hline \multirow{2}{*}{$\begin{array}{l}\text { What happens to the } \\
\text { animals in the river } \\
\text { when the excessive } \\
\text { growth of green } \\
\text { algae appears? }\end{array}$} & \multicolumn{2}{|c|}{$\begin{array}{l}\text { Animals in the water } \\
\text { may not reproduce, } \\
\text { because they do not } \\
\text { have the space. }\end{array}$} & \multicolumn{2}{|c|}{$\begin{array}{l}\text { Animals in the water die } \\
\text { because the } \\
\text { decomposition of the } \\
\text { plants consumes oxygen. }\end{array}$} & \multicolumn{2}{|c|}{$\begin{array}{l}\text { The number of animals } \\
\text { in the water is } \\
\text { increased because they } \\
\text { have a lot of food. }\end{array}$} & \multicolumn{2}{|c|}{$\begin{array}{l}\text { The animals } \\
\text { are moving to } \\
\text { another river. }\end{array}$} \\
\hline & $\mathrm{f}$ & $\%$ & $\mathrm{f}$ & $\%$ & $\mathrm{f}$ & $\%$ & $\mathrm{f}$ & $\%$ \\
\hline Grade 1 & 20 & 13.9 & 88 & 61.1 & 22 & 15.3 & 14 & 9.7 \\
\hline Grade 2 & 18 & 13.1 & 82 & 59.9 & 30 & 21.9 & 7 & 5.1 \\
\hline
\end{tabular}

The fourth item (Table 5) was related to the fate of the animals in the river if the excessive plant growth appears because of the high concentration of fertilizers and plants' decomposition after dying. Also here the students of both grades share the same opinion, since the most common answer was that animals die in water because the decomposing plants consume oxygen. It is encouraging that students understand the meaning of the eutrofication of the surface waters and that decomposition of the plants with bacteria causes the decrease of dissolved oxygen in the water. Because of this the animals can suffocate.

Table 6. Frequencies and proportions of individual responses to the fifth item in both grades

\begin{tabular}{|c|c|c|c|c|c|c|c|c|}
\hline \multirow[t]{2}{*}{$\begin{array}{l}\text { What can you } \\
\text { conclude if there are } \\
\text { no fish in the water? }\end{array}$} & \multicolumn{2}{|c|}{$\begin{array}{l}\text { The water is too } \\
\text { polluted for fish and } \\
\text { plants. }\end{array}$} & \multicolumn{2}{|c|}{$\begin{array}{l}\text { The water is too } \\
\text { cold for fish and } \\
\text { plants. }\end{array}$} & \multicolumn{2}{|c|}{$\begin{array}{l}\text { The water is rushing } \\
\text { too much for fish and } \\
\text { plants. }\end{array}$} & \multicolumn{2}{|c|}{$\begin{array}{l}\text { The water is too } \\
\text { warm for fish and } \\
\text { plants. }\end{array}$} \\
\hline & $\mathrm{f}$ & $\%$ & $\mathrm{f}$ & $\%$ & $\mathrm{f}$ & $\%$ & $\mathrm{f}$ & $\%$ \\
\hline Grade 1 & 130 & 90.3 & 7 & 4.9 & 6 & 4.2 & 1 & 0.7 \\
\hline Grade 2 & 128 & 93.4 & 4 & 2.9 & 2 & 1.5 & 3 & 2.2 \\
\hline
\end{tabular}


The fifth item (Table 6) was asking the students about what they can conclude if there are no fish and plants in the water. Most of the students from both groups selected the same answer, the water is too polluted for fish and plants. This result indicates, that students can connect lifeless ecosystem with pollution. The discussion in media about the pollution is usually connected with the negative effects on the living organisms in the water. Media also report massive deaths at least two times a year in Slovenia, so students in secondary school undoubtedly came across this information at least in the media reports if not in the formal education.

Table 7. Frequencies and proportions of individual responses to the sixth item in both grades

\begin{tabular}{llccccccc}
\hline $\begin{array}{l}\text { What does it } \\
\text { mean that the } \\
\text { river has a } \\
\text { self-cleaning } \\
\text { function? }\end{array}$ & $\begin{array}{l}\text { The rivers clean } \\
\text { themselves by } \\
\text { disposing of the waste } \\
\text { materials on the banks. }\end{array}$ & $\begin{array}{l}\text { The rivers clean themselves } \\
\text { and neutralize the waste } \\
\text { material by microorganisms } \\
\text { that live in them. }\end{array}$ & $\begin{array}{l}\text { The rivers carry } \\
\text { away waste } \\
\text { materials into } \\
\text { the sea. }\end{array}$ & $\begin{array}{l}\text { The rivers dispose of } \\
\text { the waste materials } \\
\text { on the bottom of } \\
\text { riverbed. }\end{array}$ \\
\hline $\begin{array}{l}\text { Grade 1 } \\
\text { Grade 2 }\end{array}$ & 57 & 39.6 & 63 & 43.8 & 10 & 6.9 & 14 & 9.7 \\
\hline
\end{tabular}

In the sixth item (Table 7) students had to select the right answer about the rivers' self-cleaning abilities. Students from the first and second grade most frequently selected the answer B, which explained that the rivers themselves degrade and neutralize the waste material by microorganisms that live in the water and on the bottom of the rivers. In the first grade less than $50 \%$ of students understand the rivers' self-cleaning abilities, but in the second grade of the secondary school more students (almost 60\%) know that rivers can clean themselves. But on the other hand, quite a lot of students, almost $40 \%$ in the first and $22 \%$ in the second grade think that rivers clean themselves by disposing the waist material on its banks. This is also understandable, because students can see different material, especially plastics that are disposed by the high waters, on the river banks.

Table 8. Frequencies and proportions of individual responses to the seventh item in both grades

\begin{tabular}{lcccccccc}
\hline $\begin{array}{l}\text { What can we find with } \\
\text { chemical indicators of }\end{array}$ & $\begin{array}{l}\text { The presence of } \\
\text { microorganisms. }\end{array}$ & \multicolumn{2}{c}{$\begin{array}{l}\text { The presence of } \\
\text { plants and animals. }\end{array}$} & $\begin{array}{l}\text { Colour, odour and } \\
\text { clarity of the water. }\end{array}$ & \multicolumn{2}{c}{$\begin{array}{l}\mathrm{pH} \text {, hardness, presence of } \\
\text { different substances in water. }\end{array}$} \\
\cline { 2 - 9 } & $\mathrm{f}$ & $\%$ & $\mathrm{f}$ & $\%$ & $\mathrm{f}$ & $\%$ & $\mathrm{f}$ & $\%$ \\
\hline Grade 1 & 21 & 14.6 & 9 & 6.3 & 25 & 17.4 & 89 & 61.8 \\
Grade 2 & 18 & 13.1 & 5 & 3.6 & 36 & 26.3 & 78 & 56.9 \\
\hline
\end{tabular}

The seventh question was asking the students if they know what we can find with chemical indicators of water pollution. Students of both grades have tended to choose the answer d, $\mathrm{pH}$, water hardness, the presence of different substances in water. It is interesting that first grade students were more successful at the last item, than their second grade counterparts. It is true that the difference is not significant, but students in the first grade identified the analysis of the different substances in the water as the chemical analysis. This is in consistence with the fact that first grade students were involved in the chemistry education in the time of the research, but one year has passed since the second year students participated at the chemistry lessons.

\section{Conclusions}

The curriculum of a secondary medical school contains environmental content only as a part of the chemistry, but in a very small extent (e.g. know the main air pollutants; carbon dioxide, sulphur dioxide, nitrogen oxides, ozone, chlorofluorocarbons (CFCs), smog and the consequences of air pollution; acid rain, greenhouse effect, ozone layer destruction, know the drinking water main pollutants; phosphates, nitrates, pesticides, exploring the resources and consequences of major pollutants of soil; fertilizers, biocides, detergents, petroleum products ... ) (http://portal.mss.edus.si/msswww/programi2011/programi/Ssi/KZ-IK/katalog.htm). Most often the content is related to general knowledge on environmental issues. General knowledge of the factors of river pollution can be assessed as good. We expected that the knowledge of the factors in our education had improved, which we can prove and confirm with our research, which showed that the students of the second grade were more successful than the students of the first grade, because they have already had biology and chemistry classes. We found out, 
that there are statistically significant differences between the knowledge of the river pollution of the first-grade students and the second-grade students. But on the other hand it should be emphasised that the average knowledge of the topic is still quite average and it should be improved. It is expected that the knowledge of river pollution factors is different between boys and girls. It would be advisable to carry out a research that would evaluate the difference in knowledge according to gender and the factors that influence the gender differences. Researches (González-Gaudiano, 2007; Campbell et al., 2010) show that environmental contents are interesting for the students ' population. In Slovenia these topics are insufficiently integrated into the chemistry, biology, nutrition and ultimately health care curriculums. Environmental context has a great effect on healthy lifestyle, health and general welfare of the individuals. It would be sensible to add a subject to the curriculum of secondary medical schools that would acquaint students with the most pressing problems of pollution of our environment which is also one of the key factors that greatly affect the health and welfare of the individual. The problem is that there are constantly new topics that could be integrated into the curriculum, but in the end only few are (Yueh, Cowie, Barker, \& Jones, 2010). Because of this teachers of the specific subject should decide which topics are the most interesting and have the potential to motivate students to learn science. In an effort to promote the emergence of a subject, such as environmental education, it is necessary to consider the participation of the local environment, links with a national network of cooperation and, ultimately, participation of a school. Without these factors, the fight for integration of the subject in the curriculum is difficult (Yueh et al., 2010). Conde and Sánchez (2010) describe the various ways in which environmental education should be included in the curriculum. One way is the so-called "sword" model, which touches on all curriculum areas as a supplement in the form of isolated or occasional workshops, activities, either inside or outside the school context. Pujol and Bonil (2003) see a "greening" of the curriculum as a complex and dynamic process, built on three main foundations: (1) a new collective ethic, (2) a new style of thinking and (3) a new form of transformation of operation. It may be worthwhile to conduct a research among chemistry and biology teachers, as this would determine how they themselves deal with the environmental issues and how do they integrate these topics into their teaching. On this basis, we would get a clearer picture of why some students know the factors of pollution much better than others and what are the factors that influence the students' understanding of the environmental issues. It would be also important to develop a model for applying the environmental content into the science subject in Slovenian schools. This model could be developed according to the extensive results obtained by the study of the wide range of different variables that influence teaching and learning of environmental issues.

\section{References}

Arcury, T. (1990). Environmental attitude and environmental knowledge. Human Organization, 49(4), 300-304.

Ballantyne, R. (1995). Environmental teacher education: Constraints, approaches and course design. International Journal of Environmental Education and Information, 14(2), 115-128.

Benton, G. M., Farmer, J., \& Knapp, D. (2007). An Elementary School Environmental Education Field Trip: Long-Term Effects on Ecological and Environmental Knowledge and Attitude Development. Journal of Environmental Education, 38(3), 33-42. http://dx.doi.org/10.3200/JOEE.38.3.33-42

Campbell, T, Medina-Jerez, W., Erdogan, I., \& Zhang, D. (2010). Environmentally educated teachers: The priority of priorities? Connect, XV(1), 1-3. Exploring science teachers' attitudes and knowledge about environmental education in three international teaching communities. International Journal of Environmental \& Science Education, 5(1), 3-29.

Conde, M., \& Sánchez, J. S. (2010). The school curriculum and environmental education: A school environmental audit experience. International Journal of Environmental \& Science Education, 5(4), 477-494.

Cutter-Mackenzie, A. (2003). Eco-Literacy: The “Missing Paradigm” in Environmental Education. Unpublished doctoral dissertation, Central Queensland University, Brisbane.

Davis, J. M., \& Elliott, S. (2003). Early childhood environmental education: Making it mainstream. Research into Practice. Early Childhood Australia, Inc., the Journal of Environmental Education, 38(3), 33-42.

Fien, J., \& Tilbury, D. (1996). Learning for a sustainable environment: An agenda for teacher education in Asia and the Pacific. Bangkok: UNESCO.

Flowers, R., Guevara, J., \& Whelan, J. (2009). Popular and Informal environmental education - The need for more research in an 'emerging' field of practice Report. Zeitschrift fur Weiterbildungsforschung, 32(2), 36-50.

Goldman, D., Yavetz, B., \& Peer, S. (2006). Environmental literacy in teacher training in Israel: Environmental behavior of new students. Journal of Environmental Education, 38(1), 3-22. http://dx.doi.org/10.3200/JOEE.38.1.3-22 
González-Gaudiano, E. (2007). Schooling and environment in Latin America in the third millennium. Environmental Education Research, 13(2), 155-169. http://dx.doi.org/10.1080/13504620701295684

Jenkins, K. (1999-2000). Listening to secondary pre-service teachers: Implications for teacher education. Australian Journal of Environmental Education, 15(16), 45-56.

Jeronen, E., Jeronen, J., \& Raustia, H. (2009). Environmental education in Finland - A case study of environmental education in nature schools. International Journal of Environmental and Science Education, 4(1), 1-23.

Kaplowitz, M., \& Levine, R. (2005). How environmental knowledge measures up at a Big Ten university. Environmental Education Research, 11(2), 143-160. http://dx.doi.org/10.1080/1350462042000338324

Mastrilli, T. (2005). Environmental education in Pennsylvania's elementary teacher education programs: A statewide report. Journal of Environmental Education, 36(3), 22-30. http://dx.doi.org/10.3200/JOEE.36.3.22-30

McCue, C. (2003). Environmental Education. Environmental Encyclopedia.

McKeown-Ice, R. (2000). Environmental education in the United States: A survey of pre-service teacher education programs. The Journal of Environmental Education, 32(1), 4-12. http://dx.doi.org/10.1080/00958960009598666

Miles, R., \& Cutter-Mackenzie, A. (2006). Environmental Education: Is it really a Priority in Teacher Education? In S. Wooltorton, \& D. Marinova (Eds.), Sharing wisdom for our future, Environmental education in action. Proceedings of the National Conference of the Australian Association for Environmental Education. Sydney: Australian Association for Environmental Education (1-6).

Ministry of National Education of Turkey [MNE]. (2005). Illköğretim fen ve teknoloji dersi (6-8 ınıflar) ögretim programı (Elementary school science and technology curriculum (grades 6-8). Ankara, Turkey.

North American Association of Environmental Education [NAAEE]. (2009). The Tbilisi Declaration: Final report intergovernmental conference on environmental education. Tbilisi, USSR, 14-26. October 1977, Paris, France. Retrieved March 10, 2009, from http://www.naaee.org

O'Connor, M., \& Pooley, J. A., (2000). Environmental Education and Attitudes: Emotions and Beliefs are What is Needed. School of Psychology at Edith Cowan University in Perth, Australia, 32(5), 711-723.

Palmer, J., \& Neal, P. (1994). The handbook of environmental education. London: Routledge.

Poberžnik, A., Turk, M., Malek, N., Kožlakar, R., Banik, A., \& Skvar, M. (2007). Katalog znanja kemija. [Chemistry knowledge catalogue]. Retrieved February 9, 2011, from http://www.zrss.si

Powers, A. L. (2004). Teacher preparation for environmental education: Faculty perspectives on the infusion of environmental education into pre-service methods courses. The Journal of Environmental Education, 35(3), $3-12$.

Pujol, R. M., \& Bonil, J. (2003). Una propuesta de ambientalización curricular desde la formación científica: el caso del crecimiento urbano. En M. Junyent, A. Mª . Geli y E. Arbat (eds.), Ambientalización Curricular de los Estudios Superiores. 2: Proceso de Caracterización de la Ambientalización Curricular de los Estudios Universitarios (pp. 151-171). Girona: Universidad de Girona - Red ACES.

Spork, H. (1992). Environmental education: A mismatch between theory and practice. Australian Journal of Environmental Education, 8, 147-166.

Teksoz, G., Sahin, E., \& Ertepinar, H. (2010). A new vision for chemistry education students: Environmental education. International Journal of Environmental \& Science Education, 5(2), 131-149.

Theodore, S. M. (2000). Elements of success in environmental education through practitioner eyes. Journal of Environmental Education, 31(3), 4-11. http://dx.doi.org/10.1080/00958960009598639

Tilbury, D. (1992). Environmental education within pre-service teacher education: The priority of priorities. International Journal of Environmental Education and Information, 11(4), 267-280.

Tilbury, D. (1993). A grounded theory of curriculum development and change in environmental education at the teacher education level. Unpublished paper presented at the UNESCO Asia - Pacific Region Seminar on Environmental Education and Teacher Education, Griffith University.

Tilbury, D. (1994). The International development of environmental education: A basis for a teacher education model? The International Journal of Environmental Education and Information, 13(1), 1-20. 
Yueh, M. M., Cowie, B., Barker, M., \& Jones, A. (2010). What influences the emergence of a new subject in schools? The case of environmental education. International Journal of Environmental \& Science Education, $5(3), 265-285$.

Zupančič, G., Vičar, M., Gobec, K., \& Mršić, H. (2007). Katalog znanja biologija [Biology knowledge catalogue]. Retrieved February 9, 2011, from http://www.zrss.si 